\title{
Surficial glaciology of Jakobshavns Isbræ, West Greenland: Part I. Surface morphology
}

\author{
K. Echelmeyer, T. S. Clarke and W. D. Harrison \\ Geophysical Institute, University of Alaska Fairbanks, Fairbanks, Alaska 99775-0800, U.S.A.
}

\begin{abstract}
Jakobshavns Isbræ is a large, fast-moving ice stream/outlet glacier in West Greenland which ends at a floating, calving front. It drains about $6.5 \%$ of the area of the Greenland ice sheet. Studies of its surface morphology are described in this paper. The surface is relatively steep $(0.01-0.03)$ and the thickness is large (up to $2600 \mathrm{~m}$ along the center line (Clarke and Echelmeyer, 1989)), indicating very high driving stresses $(200-300 \mathrm{kPa})$. The ice stream is about $6 \mathrm{~km}$ wide and $85-90 \mathrm{~km}$ long, all of which is in an area of surface melting. The base of the ice stream, and of much of the drainage area, is below sea level. Marginal crevasse zones have a width on the order of the width of the ice stream itself. Unique surficial features are ice blisters and lakes; the latter have a sequence of ogive-like features on their floating ice cover which can be used to determine velocity. There is a pinning point near the terminus which may act as a stabilizing influence, possibly playing a role in halting, at least temporarily, a recent retreat of the terminus. Ice-thickness estimates at the terminus lead to a flux which is less than previously assumed by others (e.g. Bindschadler, 1984; Pelto and others, 1989) when estimating Jakobshavns Isbræ's drainage basin to be nearly in balance.

The driving stresses on Jakobshavns Isbræ are an order of magnitude higher than those of the ice streams of West Antarctica. Its crevasse patterns are much less localized. Its relatively unconfined terminus is more comparable to that of relatively unbuttressed ice streams such as Pine Island and Thwaites Glaciers than it is to other West Antarctic ice streams which terminate in large, confined ice shelves.
\end{abstract}

\section{INTRODUGTION}

Jakobshavns Isbræ (Greenlandic: Sermeq Kujatdleq) is a large, fast-moving glacier in West Greenland (Fig. 1). It is variously dubbed an outlet glacier, an ice stream and a tide-water glacier. The glacier drains about $6.5 \%$ of the total area of the Greenland ice sheet. It persists almost 85$90 \mathrm{~km}$ inland (about 15 times its width) as a well-defined stream of ice moving at speeds much greater than the surrounding ice sheet, and has heavily crevassed shear margins. For comparison, the ice streams of West Antarctica, such as Ice Streams B and C, extend into the ice sheet as well-defined streams about ten times their width, which is $\sim 35-50 \mathrm{~km}$. Jakobshavns Isbre enters Disko Bay at the upper end of a long, partially ice-choked fiord. However, unlike many tide-water glaciers (such as those in Alaska), this glacier does not terminate at the grounding line. Instead, it ends in a floating terminal lobe extending about $10-14 \mathrm{~km}$ beyond the grounding zone, being confined within the fiord walls. Calving at the terminus produces many large icebergs (up to $2 \mathrm{~km}^{3}$ in size) which float down the fiord to a shoal at its mouth near the village of Ilulissat (Jakobshavn). The calving flux is estimated to be $\sim 60 \times 10^{6}$ tonnes $\mathrm{d}^{-1}$. These icebergs pass the shoal, some only after being reduced in size by ablation and fracture, and enter Disko Bay and Davis Strait, where they have profound effects on shipping and oil production in the waters of western Greenland and northeastern Canada.

Jakobshavns Isbræ may be the world's fastest-moving glacier in a non-surge state. Continuous speeds of up to $7 \mathrm{~km} \mathrm{a}^{-1}$ are reached near the terminus (Carbonnell and Bauer, 1968; Lingle and others, 1981; Echelmeyer and Harrison, 1990). These high speeds have persisted for at least 25 years, and thus do not seem to be part of a periodic surge cycle in the normal sense. Significant seasonal variations in speed are non-existent (Echelmeyer and Harrison, 1990). At shorter time-scales, however, the speed does fluctuate, at least on the lower glacier where fluctuations on the order of $35 \%$ have been observed at tidal frequencies (paper in preparation by K. A. Echelmeyer).

Seismic reflection studies show that the bed of Jakobshavns Isbræ is well below sea level as far inland as $100 \mathrm{~km}$ (Clarke and Echelmeyer, 1989). The thickness of the ice is such that, even if it were removed, isostatic 


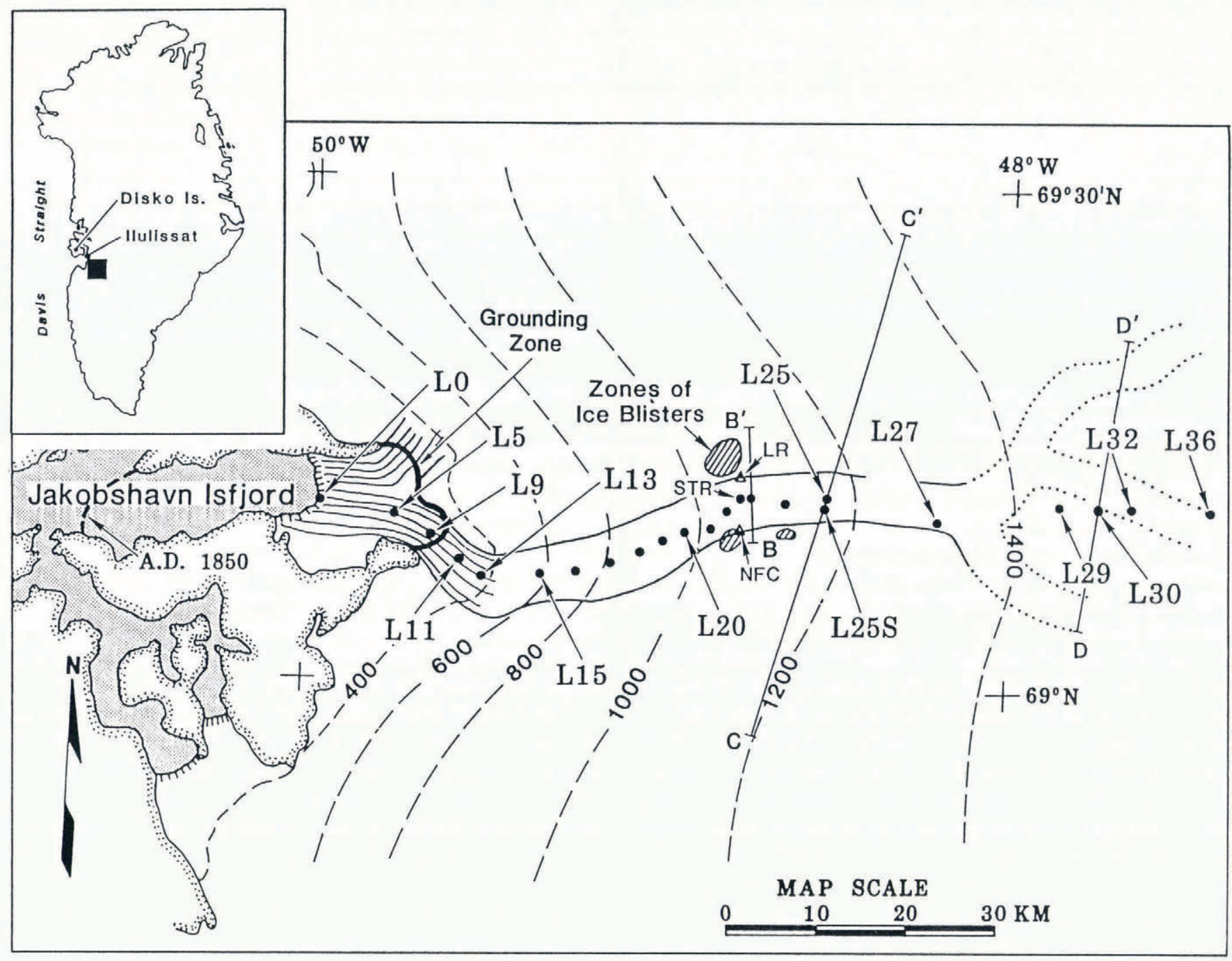

Fig. 1. Map of Jakobshavns Isbre, showing ice-stream margins, the grounding zone, the location of some of the markers described in the text, and regions where ice blisters are found. Also shown are the terminal position in 1850 (from Weidick, 1990), locations of three transverse elevation and velocity profiles, and approximate elevation contours in meters (personal comunications from $H$. Brecher and T. Hughes).

equilibration would be insufficient to raise the bedrock above sea level. Thus, Jakobshavns Isbræ is a marine-type outlet glacier draining a marine ice sheet (see, for example, Radok and others (1982) for central Greenland bedrock elevations). As such, it could be unstable and subject to rapid retreat in a mode similar to that described for a tidewater glacier (Meier and Post, 1987) or an unbuttressed marine ice sheet (Hughes, 1975). There is, however, a pinning point beneath the floating terminus downstream of the grounding zone which may contribute to the quasistability of this glacier in a manner similar to that described by Thomas (1979) for West Antarctic ice-shelf/ ice-stream systems, and as further discussed by Hughes (1986, in press).

The rapid speed and possible classification as either an outlet glacier of a marine ice sheet, an ice stream and/or a tide-water glacier make studies on Jakobshavns Isbræ helpful in addressing many important topics such as the mechanisms of rapid glacier flow, and ice-stream and tidewater-glacier dynamics. It is interesting to compare the processes involved in the flow of Jakobshavns Isbræ with those of the ice streams of West Antarctica, with the aim of understanding the response to climatic change. Jakobshavns Isbre, like, for instance, Pine Island and Thwaites Glaciers, is not buttressed by a large, confined ice shelf. On the other hand, Ice Streams A through E in Antarctica do flow into an ice shelf. Such buttressing is thought to play a key role in the stability of the latter ice streams, and yet, somewhat paradoxically, the former unbuttressed ice streams do not appear to be in an unstable retreat at the present time.

This is the first in a series of three papers in which we describe the surficial glaciology of the lowermost $100 \mathrm{~km}$ of Jakobshavns Isbra as determined mainly during the period 1984-86. In this paper (Part I), we describe the surface morphology, surface elevation and slope, the thickness and pinning points of the floating terminus section, lakes on the glacier and lake ogives, and the curious phenomenon of "ice blisters". Part II (Echelmeyer and others, in press) provides a description of mass balance, snow/ice facies, ice temperature and the refreezing of meltwater in firn. In the final paper, Part III 
(Echelmeyer, in press), we describe the surface-velocity field, iceberg calving and short-term fluctuations of the calving front.

Additional topics are described elsewhere, including seasonal and short-term motion studies (Echelmeyer and Harrison, 1990; paper in preparation by K. A. Echelmeyer), ice-fabric studies on shallow ice cores (Quintana and Echelmeyer, 1986), seismic studies (Power and Echelmeyer, 1986; Clarke and Echelmeyer, 1989) and a hot-water borehole drilling program with A. Iken of ETH Zürich (e.g. Iken and others, 1989; Humphrey and Echelmeyer, 1990).

\section{A BRIEF HISTORY OF THE TERMINUS OF JAKOBSHAVNS ISBRA}

Bauer (1968) and Weidick (1968, 1990) have given a detailed history of the terminal position of Jakobshavns Isbræ. It is summarized here because of its importance in interpreting present-day terminal fluctuations, calving discharge, and the position of the grounding zone and pinning points.

At the end of the last ice age, ice retreated from a position near the west end of Disko Island to the mouth of Jakobshavns Isfjord near the village of Ilulissat. Here a submarine moraine shoal of depth $\sim 200-300 \mathrm{~m}$ which extends about $5 \mathrm{~km}$ out into Disko Bay marks a quasistationary terminus position at around 8000 BP. Today, large icebergs, some with a draft up to $600 \mathrm{~m}$, travel down the fiord and become stranded on this shallow submarine shoal. Only after the icebergs melt, break apart and are lifted during high tides do they float free and move on into Davis Strait.

The ice then retreated until about $5000 \mathrm{BP}$, when the ice sheet reached its minimum extent in this region, inland of its present position. Following this retreat, the glacier advanced until, in 1850 , it reached a position about halfway along the present fiord (Fig. 1). Trim lines show that the ice surface corresponding to this 1850 maximum was about $200 \mathrm{~m}$ above the present calving front. Because the fiord depth is $1000-1500 \mathrm{~m}$ (personal communication from Greenlandic longline fisherman), much of the glacier must have been grounded at this time. That the larger icebergs emanating from the present-day terminus are able to drift down the fiord with no hindrance at this 1850 position means that only a limited submarine shoal (at depths below about $650 \mathrm{~m}$ ) exists at this location.

After about 1850, the glacier began to retreat back up the fiord until, in the early $1960 \mathrm{~s}$, it reached its present position. It now has a $\sim 12 \mathrm{~km}$ long floating section downstream of the grounding zone. This retreat amounted to about $30 \mathrm{~km}$, at an average rate of $0.28 \mathrm{~km} \mathrm{a}^{-1}$. Such a rate of retreat is relatively slow compared with many tidewater glaciers in Alaska, where comparable retreat rates are about $0.5-1.7 \mathrm{~km} \mathrm{a}^{-1}$ and the total retreat ranges from 20 to $100 \mathrm{~km}$.

Since about 1960, the calving front has remained relatively stable, at least in its mean position (e.g. Warren, in press; see Part III for a description of short-term fluctuations). Over the past 14 years, since the surveys of Lingle and others (1981), the surface of the floating ice tongue appears to have remained nearly constant in elevation. There may, however, have been some lowering
( $\sim-10 \mathrm{~m}$ ) since 1957 as based on a comparison of present surface elevations along the calving front with those obtained photogrammetically by Bauer (1968), which implies a substantial decrease in thickness. Similarly, the surface velocity near the calving front has remained nearly constant since 1961 based on a comparison of our results with those of Carbonnell and Bauer (1968), Lingle (1978) and Pelto and others (1989). It is likely that the glacier system is still adjusting its profile to the 100 year retreat, but there are insufficient data to determine the presence of any morphological changes inland of the grounding zone over the present 30 year period of relative stability.

\section{SURFACE MORPHOLOGY}

We begin our description of present-day Jakobshavn Isbræ with a discussion of the surface morphology. This will serve as an introduction to the features of the glacier and to fix the elevation of the various markers placed along the glacier for velocity, balance and temperature measurement. Comparison is also made with features of Antarctic ice streams (as described by Shabtaie and others (1987) and Vornberger and Whillans (1986), for example) and Antarctic outlet glaciers (McIntyre, 1985).

In the following, reference is made to features which are shown on the map in Figure 1 and in the satellite images of Figure 2. The map has been derived from a combination of terrestrial and satellite doppler surveying, analysis of aerial photogrammetry by $\mathrm{H}$. Brecher (personal communication) and satellite-image interpretation (both Landsat (Thomsen, 1987) and MOS). Figure $2 \mathrm{a}$ and $\mathrm{b}$ are parts of an enhanced MOS- 1 image taken on 7 August 1989 (pixel size: $50 \mathrm{~m}$ ).

The extent of Jakobshavns Isbræ drainage basin has been determined most recently by Bindschadler and others (1989) using satellite altimetry. The basin extends inland to the ice divide, about $550 \mathrm{~km}$ from the coast, where it is $\sim 270 \mathrm{~km}$ wide. It has an areal extent of about $1.1 \times 10^{5} \mathrm{~km}^{2}$, or $6.5 \%$ of the Greenland ice sheet. The width of this basin in its lowermost reaches ranges from $135 \mathrm{~km}$ at a distance $100 \mathrm{~km}$ inland from the coast to $40 \mathrm{~km}$ near the coast.

From the inland ice sheet down towards the coast, the glacier becomes a well-defined, fast-moving, 3-6 km wide ice stream embedded in the ice sheet (Fig. 2b). The speed of this $\sim 85 \mathrm{~km}$ long ice stream increases relative to the surrounding ice sheet towards the coast, leading to an increase in crevasse density along the margins and within the ice stream itself. The glacier is relatively steep and very broken near the grounding zone.

We use the term "grounding zone" as opposed to "grounding line" because tidal fluctuations cause large migrations of the line of ungrounding on a gently sloping bed and because the actual "line" of ungrounding is very difficult to identify (theoretically or observationally) on such a heavily crevassed glacier. The grounding zone has a longitudinal extent of several kilometers. The glacier extends $11-15 \mathrm{~km}$ downstream from the grounding zone as a heavily crevassed floating ice tongue $9-12 \mathrm{~km}$ wide (Fig. 3). The floating section moves up and down $3 \mathrm{~m}$ or so with the tide (Lingle and others, 1981; paper in preparation by K. A. Echelmeyer).

The fiord into which the glacier flows is $45 \mathrm{~km}$ long 

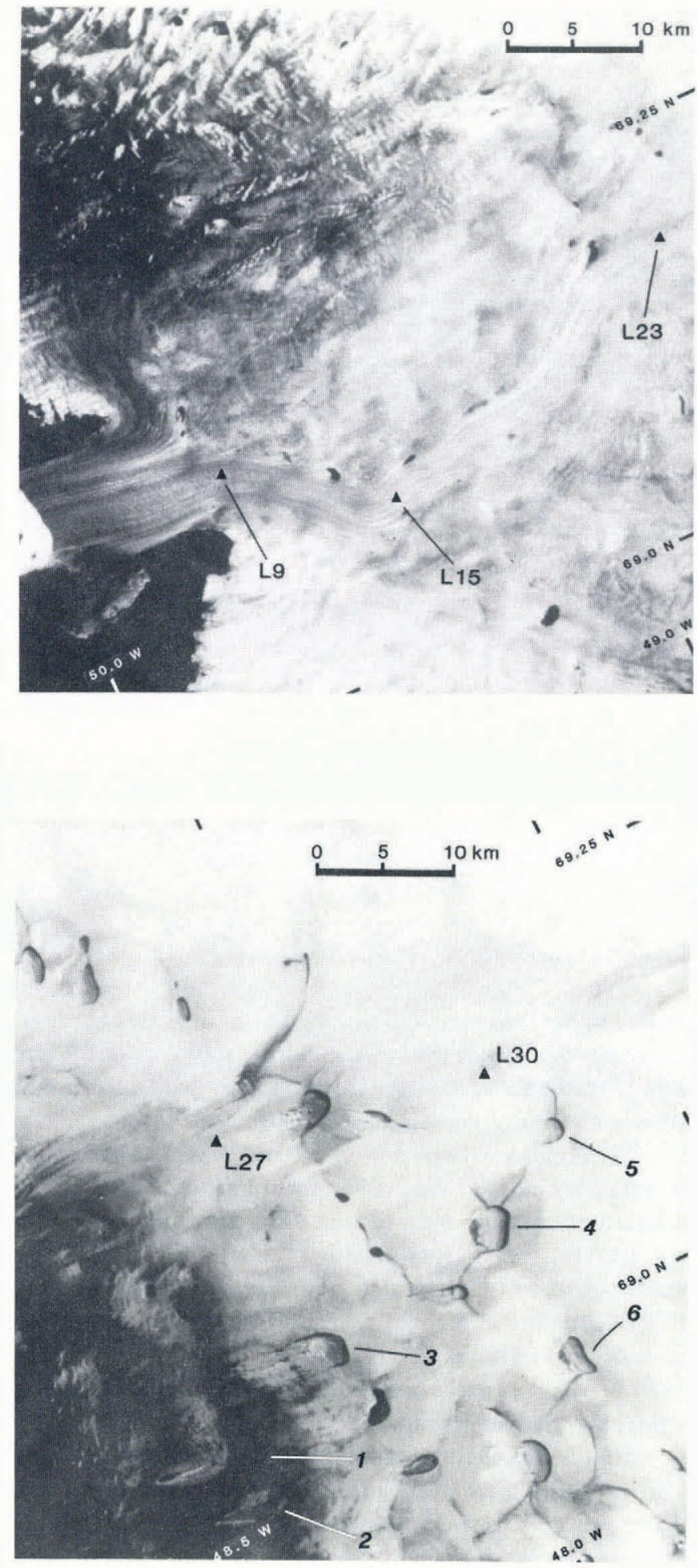

Fig. 2. (a) MOS-1 satellite image of lower Jakobshavns Isbre region, showing ice stream, fiord (covered with brash ice), "flow-line tracers", and meltwater lakes and rivers. Sensor bands 2, 3 and 4 are enhanced. The dark areas on the firn/ice are open water; the large dark area at the lower left is land and the upper left is bare ice. (b) MOS-1 image of upper ice stream. Image is a continuation of Figure $2 a$ inland. Lakes used in ogive analysis are labeled. Dark area to left is bare ice, grayer regions are wet snow.
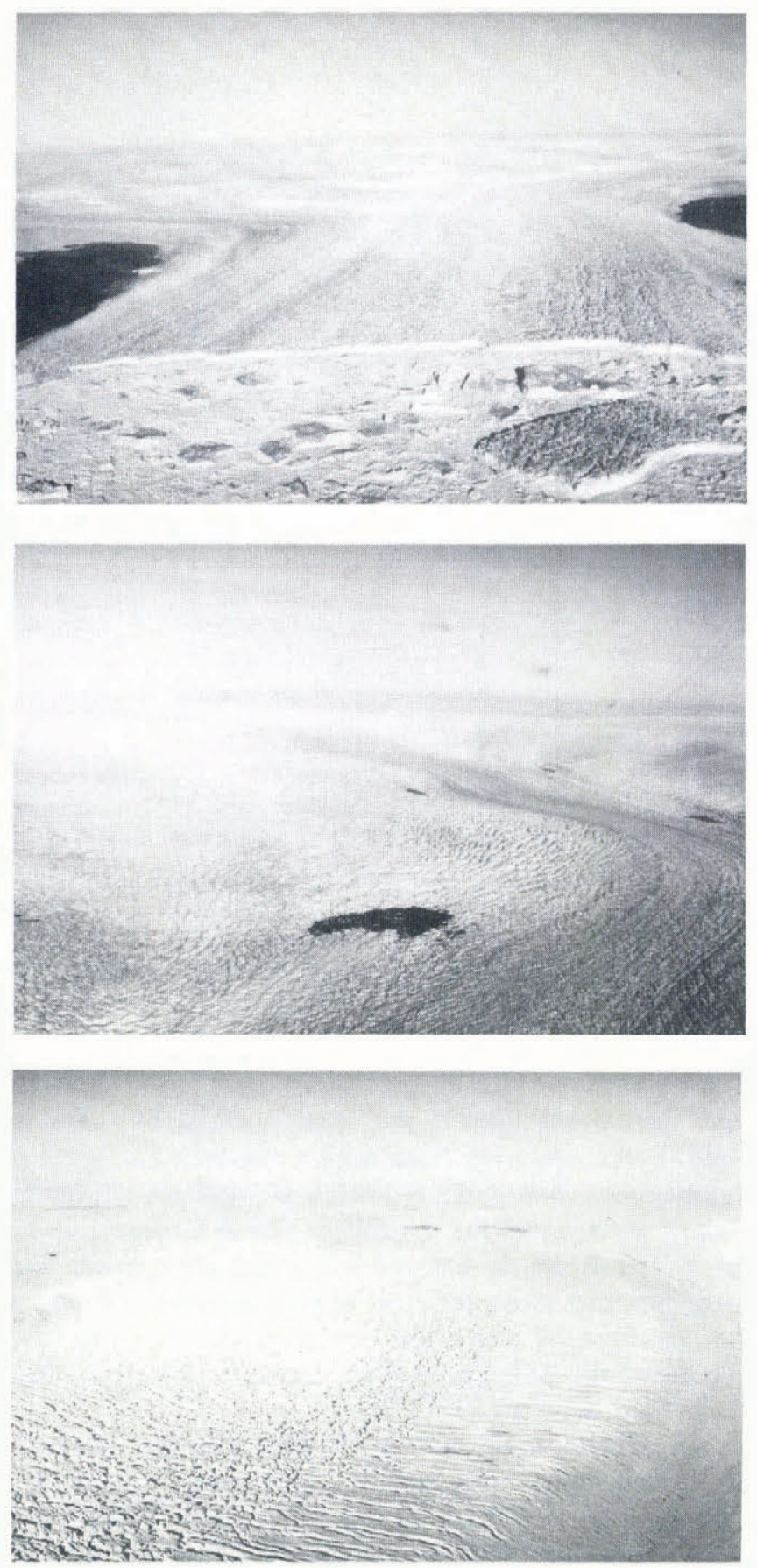

Fig. 3. (a) Photograph of the calving front and floating terminal lobe, looking up-glacier to the east. Note the two ice streams, the prominent row of crevasses (the Zipper), and the icefall between the north and south ice streams. The fiord is covered with brash ice, and the large iceberg to the right of center is about $3 \mathrm{~km}$ in length. The terminal ice cliff is 50$90 \mathrm{~m}$ high. (b) Photograph looking up the ice stream from L14 to L18. The marginal crevasse zone and flow-line tracers are apparent. (c) Photograph looking up the ice stream showing the extensive marginal crevasse field to the north in the vicinity of L20 to L23. A field of ice blisters is located near two lakes to the right of center in the upper part of the photograph. 


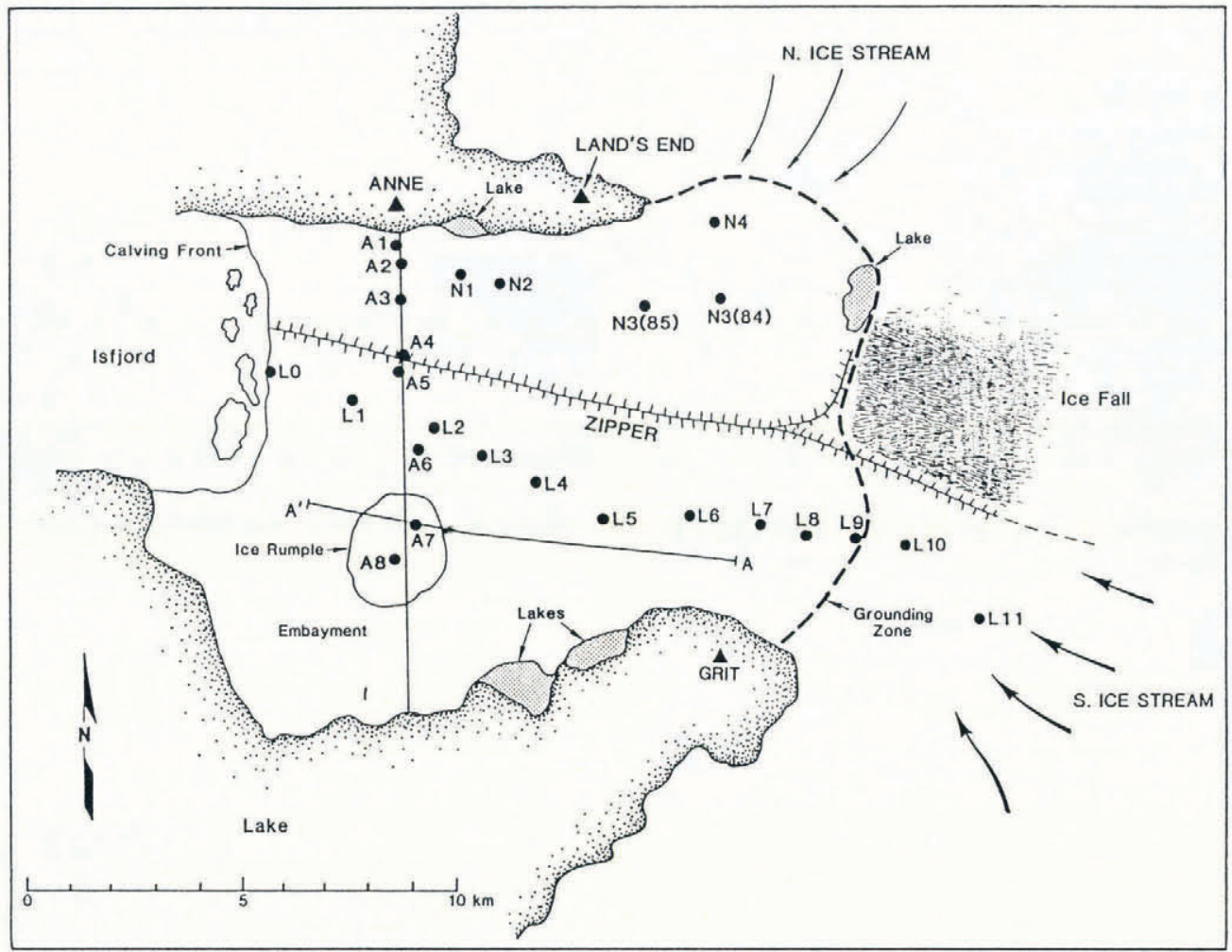

Fig. 4. Map of lower Jakobshavns Isbre, showing the location of survey points (triangles), various markers, the "ice rumple" and the embayment south of it.

from the calving front to the coast at Disko Bay, and is typically $6-9 \mathrm{~km}$ wide. Two major tributary fiords enter the main one below the terminus of Jakobshavns Isbræ. During the summer the uppermost half of the fiord, up to the glacier front, is completely choked with brash ice, bergy bits and icebergs. Little or no open water occurs in this reach, and shear-type crevasses occur along the margins of the floating ice pack. In winter the remainder of the fiord is covered with sea ice.

In addition to the main ice stream, there is a northern ice stream that is "relatively" uncrevassed above the grounding zone. These two streams join together just below the grounding zone, where the northern stream makes a sharp bend to the west into the fiord. This bend and the junction of the two ice streams is clearly shown in Figure 2a. The suture between the two ice streams forms a prominent feature along the floating tongue. This suture is made up of large seracs and, because of its similarity in appearance and function to a zipper, it has been so named by $\mathrm{T}$. Hughes (personal communication). There is a significant difference in elevation and, near its inception, in velocity across the Zipper. The slower-moving ice of the northern ice stream is accelerated by the faster-moving main stream, leading to intense crevassing along the floating part of the northern ice stream.

The calving front follows a north-south-trending arc for $7.5 \mathrm{~km}$ across the fiord (Figs $3 \mathrm{a}$ and 4 ). Along this part of the front the sheer ice cliff is from 40 to $90 \mathrm{~m}$ high. At the southern end, the cliff takes a sharp bend to the west end, then continues about $3-4 \mathrm{~km}$ to land (Fig. 4). The height of the cliff decreases to $20 \mathrm{~m}$ or so near its western end. Ice flows from an embayment to the south across this north-facing cliff, but this does not appear to contribute greatly to the calving flux of the glacier. The embayment lies along the south side of the fiord, and is about $3 \mathrm{~km}$ wide (Figs 2 and 4). On the ice surface in this embayment there is a series of wave-like structures with a wavelength of $\sim 250 \mathrm{~m}$ and an amplitude of $\sim 10 \mathrm{~m}$. A small amount of ice from this embayment calves into a shallow lake along its southern margin, but, for the most part, the ice in the bay appears to be slow-moving. Ice in the embayment itself appears to be separated from the main floating part of the ice stream by a shear zone. This shear zone begins as the marginal shear zone along the south fiord wall (near "GRIT") and extends across the front of the embayment to become the west-trending ice cliff.

The surface of the floating tongue is criss-crossed with older crevasses formed at and above the grounding zone. There are also fresh crevasses within about $5 \mathrm{~km}$ of the main calving front which trend generally sub-parallel to the active (north-south) ice cliff. These fresh crevasses are spaced at about $250 \mathrm{~m}$ intervals. These cracks may determine iceberg shape and, to a lesser extent, size. Upglacier from this region near the ice cliff to a position about $10 \mathrm{~km}$ above the grounding zone, the glacier surface is severely fractured with randomly intersecting crevasses which form a maze of seracs and chasms. Due to the intense extension and shear near the grounding zone, the depth of these crevasses often exceeds $50 \mathrm{~m}$. Few of the crevasses are water-filled in this region. In the bend of the northern ice stream, near the Zipper, the surface is a jumble of ice blocks and crevasses, indicating intense extension.

Between the two ice streams there is a large icefall (Fig. 3a). At the base of the icefall there is a depression, $10-20 \mathrm{~m}$ deep, in which lies a supra-ice lake, about $0.5 \mathrm{~km}^{2}$ 
in area. The water in this lake is brilliantly clear and, in the area in and around the lake, fills some of the crevasses. (It is interesting to ponder such water-filled and/or submerged crevasses in close proximity to the grounding zone in light of Weertman's (1973) theory of water-filled crevasses. The local stress field beneath the icefall may be compressive, which could cause crevasse closure at depth.) This lake is a semi-permanent feature, has a surface elevation of about $60 \mathrm{~m}$ a.m.s.l., and is not advected downstream, indicating it must be a dynamically supported feature. Another lake, this one filled with turbid water from a marginal stream, forms on the north side of the floating tongue between the ice and the fiord wall. This lake drains periodically in summer.

In the neighborhood of the grounding zone the ice gives the appearance of the outlet of a large reservoir, with flowlines converging into the exit and a general drawdown of the surface as the ice makes its high-speed exit.

At distances in excess of $10 \mathrm{~km}$ above the grounding zone, the ice stream becomes less severely crevassed. However, it is not until approximately $50 \mathrm{~km}$ inland that the surface is relatively unfractured along the center line of the ice stream itself. There are numerous meltwater streams and a few large moulins inland of $50 \mathrm{~km}$. From $10 \mathrm{~km}$ to about $50 \mathrm{~km}$ inland of the grounding zone there are curious, narrow, longitudinal ridge-iike features on the ice surface, $\sim 4 \mathrm{~m}$ high and $\sim 10 \mathrm{~m}$ wide, which serve as "flowline tracers", along the center line of the main ice stream (Fig. 3b). The origin of these ridges is not understood.

At a distance of $7-8 \mathrm{~km}$ above the grounding zone, where the crevassing becomes somewhat less severe, there begin to appear supraglacial lakes and water-filled crevasses. The water in these lakes is free of turbidity.

The crevasse fields along the north and south margin of the ice stream are shown in Figures 2 and 3. These fields differ from the chaotic crevasse zones which flank Ice Stream B and other ice streams of West Antarctica (e.g. the "Snake" and "Dragon" of Vornberger and Whillans (1986)). The marginal crevasse zones on these ice streams, which are $3-5 \mathrm{~km}$ wide, are narrow relative to the $30-50$ $\mathrm{km}$ width of the ice streams themselves, and the crevasses end abruptly in the slower-moving ice sheet. In contrast, Jakobshavns Isbræ's marginal zones are wide relative to the width of the ice stream, extending $5 \mathrm{~km}$ or more to each side of the $3-6 \mathrm{~km}$ wide ice stream. However, even where the ice stream shows "sharp" boundaries, measured velocity profiles (Part III) show there is a strong transport of ice across these marginal zones into the main ice stream. Furthermore, the velocity does not decrease abruptly outward as it does on Ice Stream B (paper in preparation by K. A. Echelmeyer and A. M. Mitchell). As noted, within about $35-40 \mathrm{~km}$ of the coast, the crevasse and flowline patterns give the impression of a funnel-form exit to the drainage basin. The well-defined ice stream emanating from further inland is superimposed on this funnel, retaining an identity within the convergent flow regime.

The marginal crevasse zones at more inland locations, $\sim 70 \mathrm{~km}$ from the grounding zone, are narrower than the ice stream, and thus more akin to those of the West Antarctic ice streams. About $80-85 \mathrm{~km}$ from the calving front, the definition of the ice stream disappears. The surface topography suggests that the main ice stream forms from three distinct tributaries, as shown in Figures 1 and $2 \mathrm{~b}$. Each tributary dies off indistinctly in the lowamplitude swell-and-trough topography of the ice sheet. (Visible in MOS satellite imagery is a curious feature located east of L36 which may be a continuation of the central branch of the ice stream.)

Recent seismic work (Clarke and Echelmeyer, 1989) shows that a deep bedrock channel underlies the narrow ice stream. The extensive crevassing of the shear margins marks the edges of this subglacial channel. The distinct bedrock channel appears to lose definition at the same location that the ice stream loses its definition, about 85$90 \mathrm{~km}$ inland.

\section{Coordinate system and grounding zone}

A longitudinal curvilinear coordinate system is defined with the $x$-axis oriented along the center line of the ice stream (positive up-glacier). The origin is fixed at the center of the grounding zone, where there is an inflection point. The $y$-axis is directed generally northward.

Markers, consisting of poles drilled into the ice, $2 \mathrm{~m}$ tetrahedra on the ice surface, or large pieces of cloth draped over serac pinnacles, were placed approximately along the longitudinal axis from the calving front to a point where the ice stream can no longer be identified. These markers are designated Ll to L36, respectively (Fig. 1). Additional markers were placed longitudinally up the floating section of the north ice stream (N1 to N4) and transversely across the floating ice near the terminus (Al to A8) as shown in Figure 4. These lower markers were replaced on an annual basis as their mean life expectancy was rather short. The positions of the " $A$ " markers shown in Figure 4 are the approximate locations over the period of study. All detailed discussion regarding measurements at these markers will necessarily be tied to their locations at the time of measurement, which may differ from that shown in Figure 4 because of the rapid surface speed and changing surface conditions. Further inland, transverse lines of markers were also emplaced across the ice stream at L18, L23, L25 and L30.

A survey control network was positioned on terra firma along the fiord walls (Fig. 4). In addition, a $45 \mathrm{~km}$ north-south base line was established, running approximately through ANNE, and a remote UHF transponder was located on a mountain at each end of this base line. A helicopter-borne master transponder was then used to position markers in the "L" line. Satellite doppler positioning was also utilized at some inland sites, and optical traverses were made where feasible.

L9 was considered to be the center of the grounding zone based on an abrupt change in slope from L7 to L9, the fact that short-term theodolite surveys show strong tidal uplift at L7, but not at L9 and L10, and on the physical setting and crevassing at L9. Tiltmeter measurements were attempted to define the grounding zone further, but serac tilting rendered this method unusable. No radio-echo-sounding returns could be obtained over this region and seismic methods were not feasible due to lack of suitable landing conditions. Even if the thickness were known throughout this area, the severe crevassing would make estimation of ice density, and therefore the 
condition of hydrostatic equilibrium, a difficult problem. It should also be noted that icequake activity, varying in intensity with the tidal cycle, was felt as far up-glacier as L13, about $8 \mathrm{~km}$ above L9 (personal communication from C. Petersen). Thus, tidal forcing could not, in itself, be used to define this zone. The position of the grounding zone off the center line was estimated from surface topography which showed an abrupt, steep rise in the surface.

\section{SURFAGE ELEVATION AND SLOPE}

A longitudinal profile along the central "flowline", from L1 to L36, is shown in Figure 5a. Elevation measurements were made at most of the markers using a combination of satellite doppler positioning, terrestrial surveying and helicopter pressure altimetry during 1984-86. Pressure altimetry was calibrated at sea level. An unresolved discrepancy of $20-40 \mathrm{~m}$ exists between the satellite measurements, referenced to the OSU86 Geoid (WGS72 ), and repeated helicopter altimetry, with the satellite measurements being lower than those obtained from pressure altimetry. In what follows we have accepted the satellite datum because of the difficulty of carrying controlled pressure altimetry inland, and adjusted the
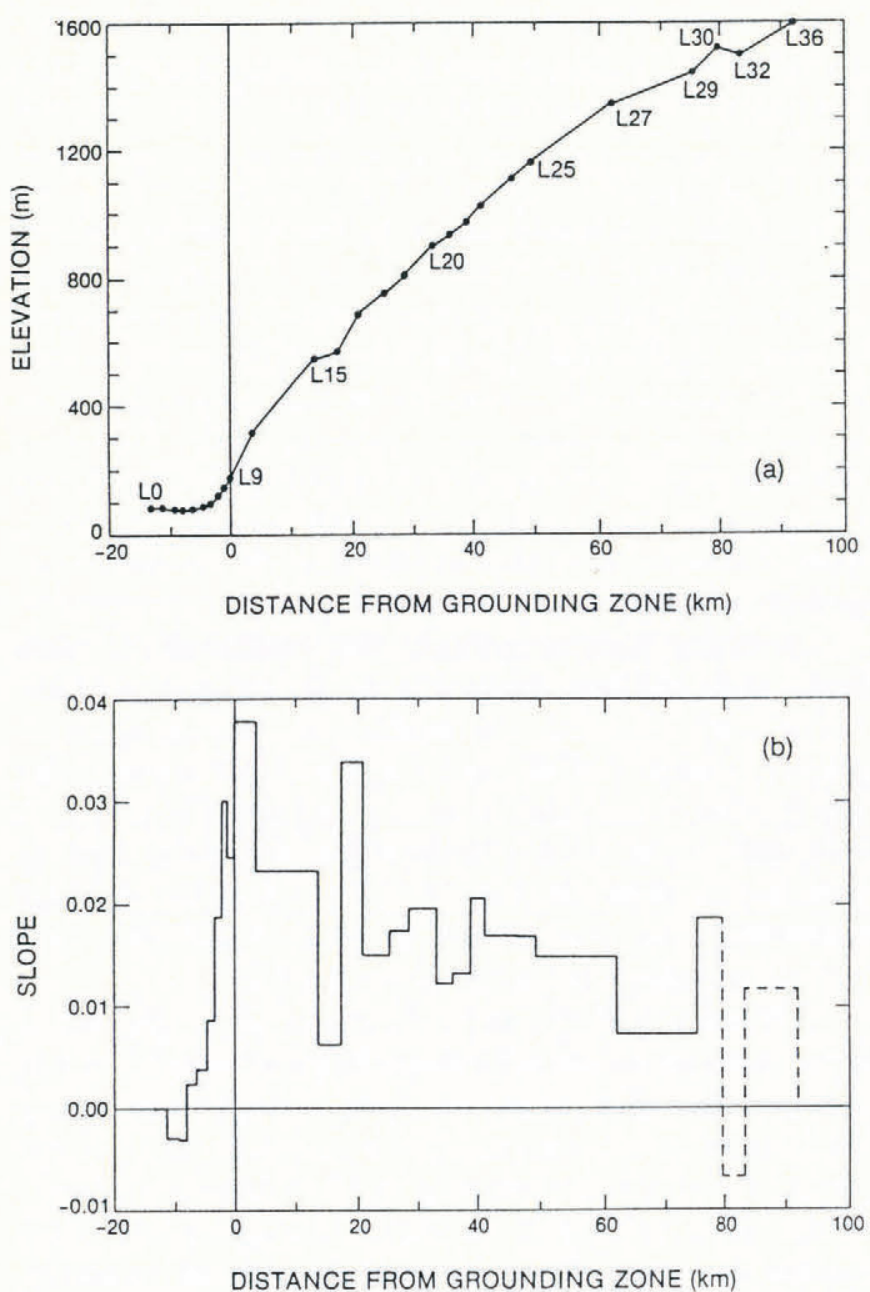

Fig. 5. (a) Elevation along the central flowline of the ice stream, June 1986. The flowline is poorly defined above $\mathrm{km} 80$ and L29 to L36 are off this flowline, as indicated in Figure 1. (b) Surface slope along the ice stream. helicopter data accordingly. Thus, absolute elevations at the helicopter sites will have a large, almost unacceptable, systematic error of $20 \mathrm{~m}$ or more. Relative helicopter elevations should be good to $\pm 6 \mathrm{~m}$ and satellite results to $\pm 1 \mathrm{~m}$. Optical elevation surveys are accurate to the decimeter level.

The profile in Figure 5a shows the sharp break in slope at L6. Upstream from this, the surface continues upward with a generally decreasing slope, giving a somewhat parabolic surface profile with average slope of 0.016 over $100 \mathrm{~km}$. The surface has irregular undulations at a scale of $5-10 \mathrm{~km}$. The decrease in surface elevation from L30 to L32 was accurately determined by an optically surveyed traverse from L29 to L36. The reason for this drop in surface elevation is that coordinate axis and surface profile do not follow a flowline in the vicinity of L30, where the channel trifurcates and becomes indistinct. Thus, stakes L30 to L36 may lie outside the central flowline region, as indicated by the dotted icestream boundaries in Figure 1.

The longitudinal profile shows no marked oversteepening at the approximate transition from sheet-like flow to stream flow (at $x \approx 80-85 \mathrm{~km}$ ), as has been described by McIntyre (1985) for outlet glaciers in Antarctica. This may be because the transition to stream flow on Jakobshavns Isbræ is not defined by a step increase in velocity, as is usually the case for Antarctic outlet glaciers. The speed at L36 is still quite large in comparison to common ice-sheet velocities (Part III) even though the ice stream is not well defined above L27. It may be that a more abrupt steepening and change in speed exists somewhere upstream of L36, but neither observations made while on a snow-machine traverse inland to about $120 \mathrm{~km}$ nor satellite imagery support this idea.

The local surface slope (Fig. 5b) was calculated along the longitudinal profile between markers. The interval between markers varied from 3 to $12 \mathrm{~km}$, or approximately one to six times the estimated ice thickness. Above $80 \mathrm{~km}$, the curve is dashed owing to the inferred divergence of the coordinate axis from the continuation of the central icestream flowline. The negative slope near the terminus may either be caused by near-front flexure (although this would normally cause the surface to drop near the calving front) or by the necessary placement of markers on tall seracs as the calving front was approached.

These surface slopes are much larger than those found on Antarctic ice streams (Shabtaie and others, 1987) and are quite comparable to Antarctic outlet glaciers such as Byrd Glacier (McIntyre, 1985). This, combined with the fact that Jakobshavns Isbræ is more than twice as thick (Clarke and Echelmeyer, 1989) as, for example, Ice Stream B (Shabtaie and others, 1987), indicates that driving stresses are on the order of 100 times those found for the West Antarctic ice streams and may be somewhat greater than those applicable to large Antarctic outlet glaciers (McIntyre, 1985).

Longitudinal profiles inland from the calving front are shown in Figure 6a, b and c. Following the line of markers $\mathrm{L} 1$ to L11, Figure $6 \mathrm{~b}$ portrays the surface as obtained from optical surveying. Because markers were necessarily located on the high points of seracs, both for visibility and logistical reasons, these elevations are several meters above the mean "effective" glacier surface. From the 


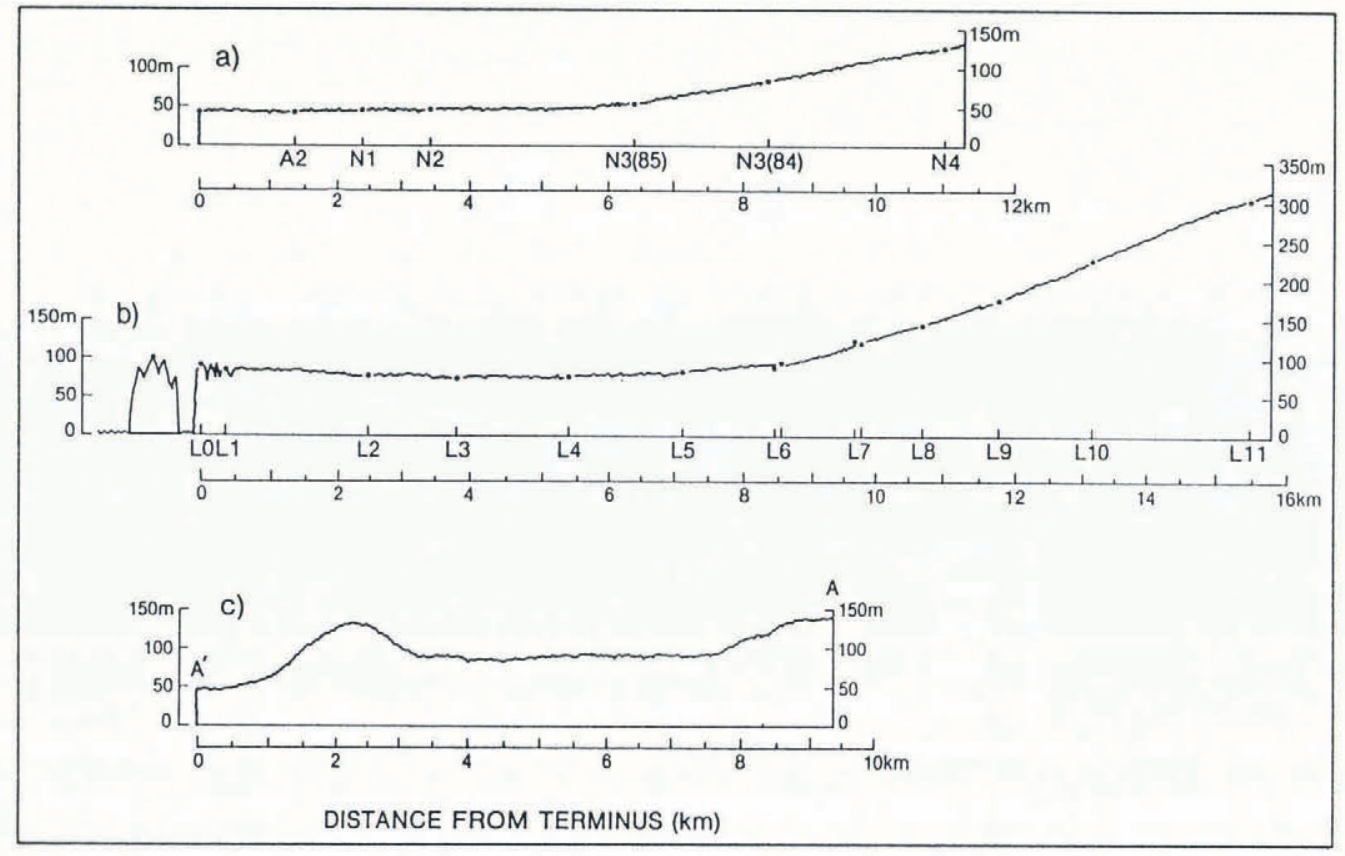

Fig. 6. Longitudinal elevation profiles along lower part of glacier. (a) North ice stream along a line from the calving front, through the " $\mathcal{N}$ " markers, to $\mathcal{N} 4$. (b) Central line up south ice stream, from an iceberg and the ice cliff near LO, along the " $L$ " line to L11. (c) Profile A-A' (Fig. 4) over the "ice rumple". Location of markers along profiles (a) and (b) are shown in Figures 4 and 1; dots represent their average optically surveyed elevations from 1984 to 1986. Profile (c) was measured using helicopter altimetry. Surface roughness is schematic.

calving front inland approximately $8 \mathrm{~km}$ the surface is nearly level to slightly rising. Beyond this the surface rises steeply up to L11.

The north ice stream is also level for several kilometers up-glacier from the front, but its surface is at a markedly lower level than the main ice stream (Fig. 6a). This difference in surface elevation implies a substantial difference in ice thickness.

An interesting feature, described in the next section, is shown on a longitudinal helicopter elevation profile about $2-3 \mathrm{~km}$ south of the L1 to L7 line (Fig. 6c). There is an abrupt bulge in the profile which is stationary in space, its position remaining constant irrespective of the position of the calving front or the time of year. Helicopter altimetry data show that the surface is about $30 \mathrm{~m}$ higher upstream of the bulge than down from it.

None of the detailed profiles (Fig. 6) shows a downwarping of the terminus as might be expected from the theoretical treatment of calving by Reeh (1968). L0 and $\mathrm{Ll}$ were lost in a calving event soon after their survey, but prior to this they were not tilted below the elevation of the mean surface defined by L2 to L4. In fact, the data show a slight up-warping as already noted. The gradual decrease in elevation along these profiles (Fig. 6) downstream from the grounding zone is related to longitudinal stretching as the ice becomes afloat and basal drag is lost (Weertman, 1957; Hughes, 1986, in press).

The transverse elevation profile along the $\mathrm{A} 1$ to $\mathrm{A} 8$ line (Fig. 4) is shown in Figure 7. Note that the Zipper is defined by a sharp step in elevation at $3 \mathrm{~km}$ from the north margin and that the mean level of the north stream is roughly $21 \mathrm{~m}$ lower than that of the southern one. The Zipper forms about $10 \mathrm{~km}$ upstream of this profile and, although it is gravitationally unstable, the elevation difference across the Zipper does not decay significantly over this $10 \mathrm{~km}$ distance. The ice-travel time to this point along the Zipper from its inception is only 1.5 years, and the fiord walls inhibit lateral flow.

The uneven structure of the north stream is related to its rapid longitudinal extension and the transverse compression caused by the strong interaction with the faster-moving and thicker ice stream to the south.

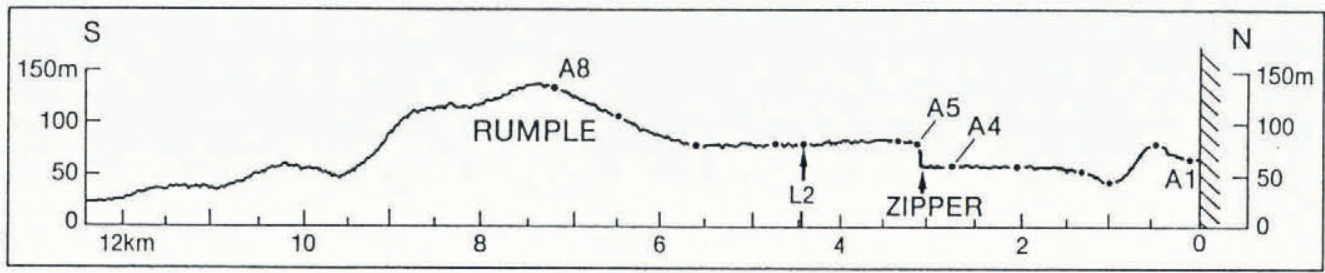

Fig. 7. Transverse elevation profile across lower floating ice lobe, extending from northern fiord wall through markers $A 1$ to A8, and into embayment to the south, as shown in Figure 4. Position of several markers in addition to A1 to A8 are shown. Average elevation, summer 1984-85. 


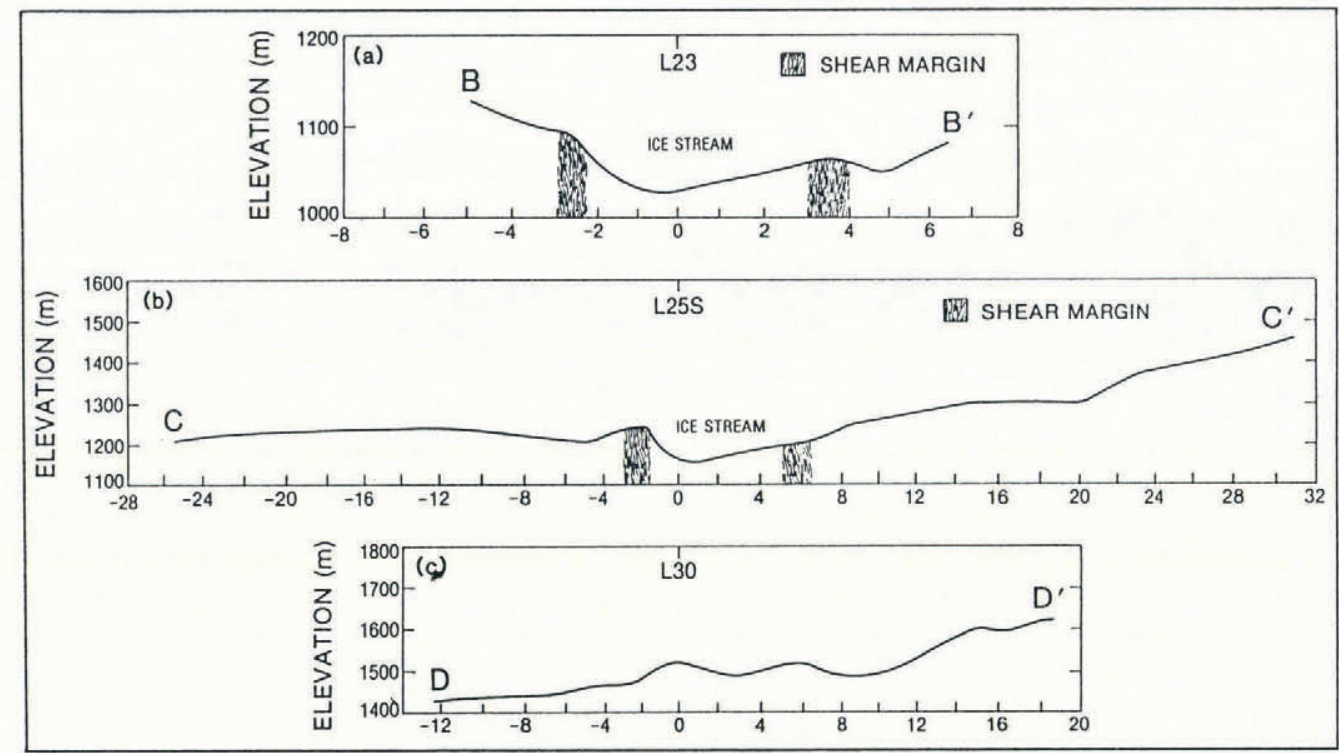

Fig. 8. Optically surveyed transverse profiles through (a) L23 (B-B') in Fuly 1988, (b) L25S (C$\left.C^{\prime}\right)$ and (c) $L 30\left(D-D^{\prime}\right)$, both in summer 1985. Vertical exaggeration of each figure is about 20 to 1. The horizontal scale of $(a)$ is different from those of $(b)$ and $(c)$.

Transverse compression from the time the north stream leaves the grounding zone until it reaches the terminus is in the range $43-50 \%$. Ice entering between the reasonably well-defined north and south ice streams (such as that pouring over the central icefall) is incorporated into the floating tongue north of the Zipper.

Transverse surface profiles across the ice stream inland at L23, L25S and L30 are shown in Figure 8a-c. Note that the ice stream is located at the center of a shallow, asymmetric concavity with an amplitude $30-60 \mathrm{~m}$ and width $4-7 \mathrm{~km}$. The wider and shallower surface trough is farthest inland. This concavity is accompanied by convergent ice flow into the main stream from the sides.

\section{THE "ICE RUMPLE" - AN EPHEMERAL STABILIZING INFLUENCE?}

Approximately $3 \mathrm{~km}$ inland from the calving front and south of the center line of the main (or southern) ice stream lies an interesting and important feature: an "ice rumple" or submerged pinning point (Fig. 4). Here, a nearly circular region, about $2 \mathrm{~km}$ in diameter, and rising $60-90 \mathrm{~m}$ above the surrounding surface, is superimposed on the floating ice tongue (Figs $6 \mathrm{c}$ and 7). The surface upstream from this ice rumple is elevated about $30 \mathrm{~m}$ with respect to that downstream of it, and the surface to the south, in the embayment, is at a much lower elevation than that to the north. Transverse surface-velocity profiles extending across this rumple show a marked decrease in speed (Part III). Conclusive evidence for a sub-ice pinning point at this location comes from short-period optical survey measurements to the tip of a serac on top of this ice rumple, as well as to several other points on the floating ice tongue. These measurements were made at $0.5-1 \mathrm{~h}$ intervals for periods of several days to weeks. Whereas the other surveyed points went up and down a few meters with the tide, the point on the ice rumple had no observable vertical motion at tidal frequencies. These results prove that the ice is not floating at this location and that it is, in fact, flowing over a submerged island. This feature is likely to have bedrock core, considering the rapid ice motion across it, which would quickly erode a non-bedrock feature such as a morainal sill. Considering the overall thickness of the nearby floating ice, this feature is probably on the order of $400-550 \mathrm{~m}$ b.s.l. As such, it may be considered to be a pinning point in the classic sense (Thomas, 1979).

Crevasse patterns show a marked divergence about the ice rumple, with some intensification upstream from it and the appearance of furrow-like features downstream toward the calving front. During our 7 years of observation (1984-90) the terminus position has fluctuated markedly about a mean location $2-3 \mathrm{~km}$ downstream from this rumple. However, no calving events have ever been observed which cause terminal retreat up to the crest of the rumple.

This ice rumple may play a significant role in stabilizing the calving front and, thus, the entire floating-ice section. As noted, the glacier retreated about $30 \mathrm{~km}$ in 100 years, coming to a halt at its present position sometime in the early 1960s. The glacier may have halted its retreat at this point because of the presence of the pinning point. This feature provides a "back-stress" to the floating ice stream (e.g. Thomas, 1979; Hughes, 1986). Such a pinning point would serve to anchor the floating calving front and stabilize its position until the point no longer provides a significant back-stress which would accompany a thinning of the ice flowing over it.

That the retreat halted, at least for the present, near the ice rumple may be somewhat fortuitous. Near this position the plan form of the fiord is somewhat divergent, with the embayment on the south and another embayment, now ice-free, just down-fiord to the north (Fig. 1). This geometry would also be expected to act as a stabilizing influence on the retreat (e.g. Warren, in 
press). In addition, back-stress applied by the ice choking the fiord may be significant. It is apparent, however, that some combination of these factors has led to a 30 year stabilization of the calving front. Thinning of the ice tongue and a decreased influx of ice from above could lead to renewed retreat.

It is important to note that trim lines show that the ice tongue was substantially thicker in the past (1800s) and thus, during the time of its retreat, this pinning point probably provided an even higher back-stress because of the increased normal stress.

\section{ICE THICKNESS AT THE CALVING FRONT}

From simple hydrostatic conditions, it should be possible to determine the thickness of ice along the entire floating section and, in particular, at the calving front, once the height of the surface is known. This works well for smooth ice shelves such as those found in Antarctica. However, the problem is not so simple for an outlet glacier such as Jakobshavns Isbræ, where the "surface" is a random series of seracs and chasms (Fig. 3a and b). Here, chasms $30 \mathrm{~m}$ or more deep penetrate an appreciable part of the overall thickness above sea level. This topography must be accounted for when calculating the ice thickness of such a glacier. Since the characteristic horizontal length scale of hydrostatic compensation is not known for the rough topography of the floating section, only a mean ice thickness for each of the two ice streams at the terminus can be determined.

Various models of the upper surface were explored in order to determine the effective height, $\langle h\rangle$, of the mean surface above sea level. $80 \mathrm{~m}$ was taken to be elevation of the serac tops along the main (south) floating ice stream, $\mathrm{L} 1$ to $\mathrm{L} 5$ and $\mathrm{A} 4$ to $\mathrm{A} 7$ are all $80 \pm 4$ m a.m.s.l. (Fig. 6). At one extreme, a sawtooth model composed of symmetrical pinnacles and cracks with a peak-to-peak amplitude of $20-30 \mathrm{~m}$ gives $\langle h\rangle=65-70 \mathrm{~m}$. Assuming a model in which flat-topped seracs $50 \mathrm{~m}$ in width are separated by 20-30 $\mathrm{m}$ deep triangular chasms, $20-30 \mathrm{~m}$ wide at the surface, gives a surface-layer void ratio of $17-27 \%$, and hence $\langle h\rangle=72-76 \mathrm{~m}$.

Thus, we find that $\langle h\rangle \approx 65-76 \mathrm{~m}$ along the center part of the south ice stream. A similar estimate for the north stream gives $\langle h\rangle=45-48 \mathrm{~m}$, assuming a peak elevation of $50 \mathrm{~m}$, as at $\mathrm{A} 2, \mathrm{~N} 1$ and $\mathrm{N} 2$ along the north stream center line, and $\langle h\rangle=54-56 \mathrm{~m}$ along the raised bench just north of the Zipper ( $58 \mathrm{~m}$ a.m.s.l. at A3).

By flying parallel to and just down-fiord from the calving front, we were able to perform helicopter pressure altimetry of the mean upper surface at the front, with direct calibration at sea level before and after profiling. One such profile is shown in Figure 9. An estimate for the deviation between this surface and the mid-plane between peaks and troughs was then subtracted to give an effective profile of the calving front. The mean effective height of the south stream front was $72-75 \mathrm{~m}$ while the northern front had a mean height of $52 \mathrm{~m}$. The elevation of the west-trending calving front along the southern embayment decreases as land is approached.

Given these effective surface elevations, we may estimate the ice thickness $H_{\mathrm{i}}$ near the calving front. From the usual hydrostatic conditions we have

$$
H_{\mathrm{i}}=\langle h\rangle /\left[1-\rho_{\mathrm{i}} / \rho_{\mathrm{sw}}\right]
$$

where $\rho_{i}$ is the bulk ice density $\left(0.90 \mathrm{Mg} \mathrm{m}^{-3}\right.$ for bubbly ice) and $\rho_{s w}$ is the density of sea water, taken to be 1.01$1.02 \mathrm{Mg} \mathrm{m}^{-3}$ depending on the salinity. The exact choice of sea-water density is uncertain because the salinity near the glacier, with its large, yet variable, input of surface and basal meltwater, is an unknown quantity. Values of the total ice thickness from Equation (1) are listed in Table 1. Fresh-water input is likely to favor a sea-water density closer to $1.01 \mathrm{Mg} \mathrm{m}^{-3}$, and, as a best estimate, the thickness of the main ice stream is taken to be $650 \pm 30 \mathrm{~m}$ while the

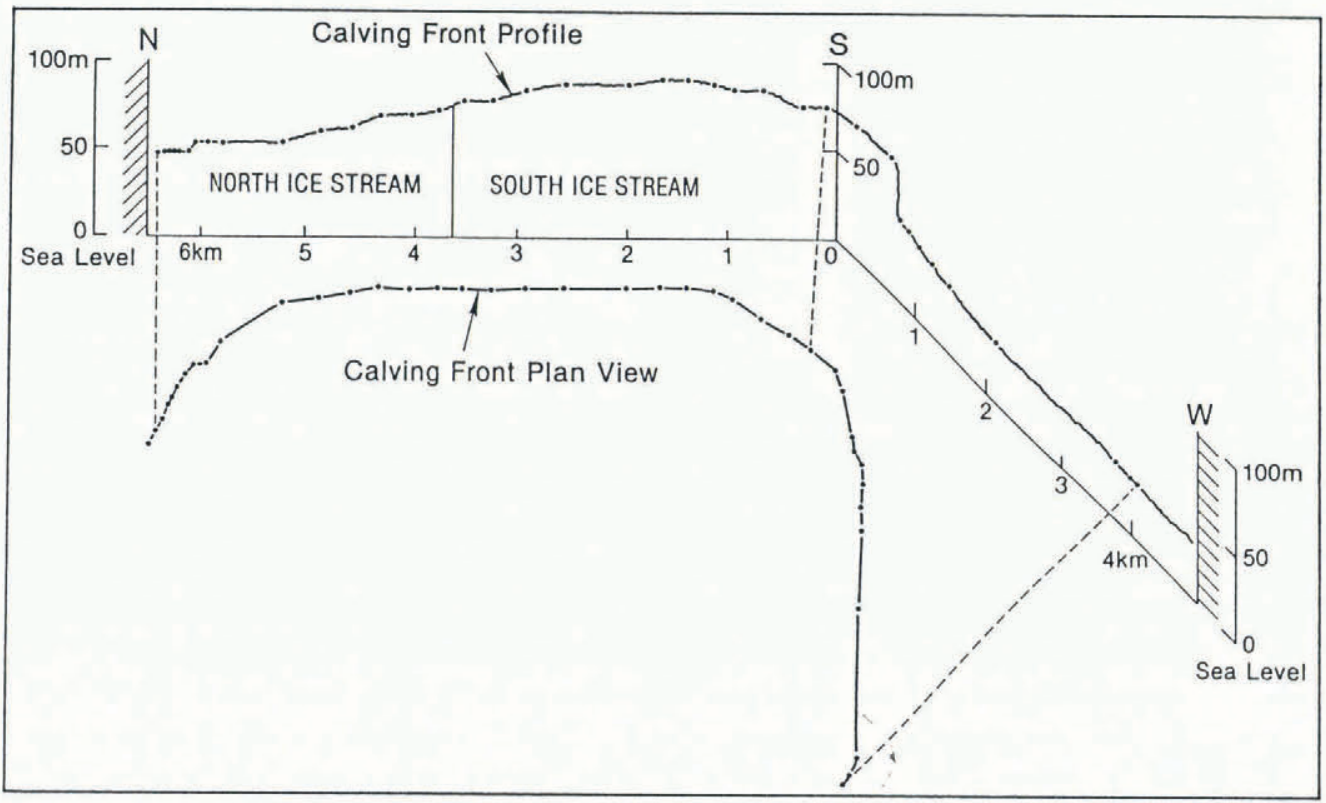

Fig. 9. Helicopter altimetry profile of the calving front on 5 0ctober 1986. Kink in profile represents the bend in the calving front from the main north-south cliff to the smaller east-west cliff. 
Table 1. Ice thickness near calving front

\section{$H_{\mathrm{i}}$}

m $\langle h\rangle$

$$
\rho_{s w}=1.01 \quad \rho_{s w}=1.02
$$

$\mathrm{m}$

$$
\mathrm{Mg} \mathrm{m}^{-3} \quad \mathrm{Mg} \mathrm{m}^{-3}
$$

$\begin{array}{cccc}\text { Main (S) ice stream } & 65 & 597 & 552 \\ & 72 & 661 & 612 \\ & 75 & 689 & 638 \\ \text { North (N) ice stream } & 46 & 422 & 391 \\ & 52 & 477 & 442 \\ & 55 & 505 & 468\end{array}$

Average calving-

front thickness

$72(\mathrm{~S})$ and

579

536 north stream is taken to be $460 \pm 30 \mathrm{~m}$ thick, giving an overall mean ice thickness of $570 \mathrm{~m}$ over the $7.5 \mathrm{~km}$ long calving ice front.

\section{Ice thickness from icebergs and comparisons with previous data}

These values of ice thickness agree with those obtained by measuring with a UHF positioning system the length of a few recently calved icebergs from the southern ice stream, which had rolled on to their sides. The measured lengths were 575,456 and $413 \mathrm{~m}$ along axes which were originally vertical (as known by direct observation of calving or from upper-surface structures which were visible). The exact location across the southern ice-stream front from which these icebergs were calved was not determined, so a more specific location for the thickness measurement cannot be given.

The mean ice thickness derived here is much less than that assumed in the past by other authors (Carbonnell and Bauer (1968), $750 \mathrm{~m}$; Bindschadler (1984), 600-800 m; Pelto and others (1989), 750-810 m). We believe that many of these previous estimates are in error because: (1) the density of pure water may have been used instead of somewhat saline sea water, and (2) some of those authors used the elevation of the upper surface rather than a weighted mean of $\langle h\rangle$ across the width of the floating ice.

However, it is interesting to note that Bauer (1968) determined the length of several iceberg cross-sections from aerial photogrammetry in 1957-58, finding an ice thickness of $660-730 \mathrm{~m}$. These values are somewhat greater than our estimated thickness and our measured iceberg lengths, the difference being $10-100 \mathrm{~m}$. Unfortunately, such a difference would be difficult to observe by comparing surface elevations along the front, since it would amount to about $2-10 \mathrm{~m}$ over very rough topography.

\section{Thickness upstream}

Given the ice thickness at the calving front, $H_{\mathrm{f}}$ (located at $x_{\mathrm{f}}$ ), the thickness $H_{0}$ at a position $x_{0}$ below the grounding zone can be estimated from the assumption of incompressibility and the observed geometry and velocity field. (The crevassed upper 40 or $50 \mathrm{~m}$ is clearly compressible, as may be the bottom surface, so the assumption of incompressibility is not strictly correct.) Flux continuity gives

$$
H_{0} \approx\left(v_{f} / v_{0}\right)\left(Y_{f} / Y_{0}\right) H_{f}
$$

where $v_{f}, v_{0}$ and $Y_{f}, Y_{0}$ are the measured velocity and icestream width at $x_{f}$ and $x_{0}$, respectively.

The north ice stream shows a strong convergence from $\mathrm{N} 3$ to the calving front, with $\left(Y_{\mathrm{f}} / Y_{0}\right) \approx 0.5$. The main ice stream actually diverges somewhat, with $\left(Y_{f} \mid Y_{0}\right) \approx 1.25$ if $x_{0}$ is taken at L6 and $\left(Y_{\mathrm{f}} / Y_{0}\right) \approx 1.5$ if $x_{0}$ is at L9. Values of $\left(\mathrm{v}_{\mathrm{f}}, \mathrm{u}_{0}\right)$ are as follows for various $x_{0}$ (in $\mathrm{m} \mathrm{d}^{-1}$, from Part III): N3, (17.0,5.4); A6, (21.0,18.8); L9, $(21.0,18.0)$. Using the results of Table 1 , we thus have $H_{\mathrm{i}} \approx 725 \mathrm{~m}$ at N3, $H_{\mathrm{i}} \approx 895 \mathrm{~m}$ at L6 and $H_{\mathrm{i}} \approx 1125 \mathrm{~m}$ at L9. Estimating the effective surface elevation from Equation (1) (with $\rho_{\mathrm{sw}}=1.015 \mathrm{Mg} \mathrm{m}^{-3}$ ) and adding an estimate for the mean serac height above this mid-plane, the following surface elevations at these upstream locations are obtained, with the measured elevation for comparison (in $\mathrm{m}$ ):

$\begin{array}{ccr}\text { Surface elevation } & \text { From Equation (1) } & \text { Observed } \\ h(\mathrm{~N} 3) & 87 & 85 \\ h(\mathrm{~L} 6) & 110 & 98 \\ h(\mathrm{~L} 9) & 142 & 177\end{array}$

The estimated surface elevations agree reasonably well with those observed at N3 and L6, which are well removed from the grounding zone, but at L9 (which is within the steep grounding zone) the correlation is poor. This may imply that L9 is well grounded, although several assumptions are implicit in the calculation leading to $h$.

\section{ICE BLISTERS, LAKES AND LAKE OGIVES}

Two groups of surface features found on Jakobshavns Isbræ that deserve special mention are the extensive fields of "ice blisters" and the large number of supraglacial lakes, some with accompanying "lake ogives".

Numerous beautiful blue lakes dot the ice sheet near the firn line in this region of West Greenland (Fig. 2a and b). They are distributed in the Jakobshavns Isbræ drainage basin at elevations from about $600 \mathrm{~m}$ up to about $1450 \mathrm{~m}$. Lakes at elevations below about $1150 \mathrm{~m}$ rest on bare glacial ice and often lose their ice cover during summer. From $1150 \mathrm{~m}$ to about $1300 \mathrm{~m}$, the lakes are within the superimposed ice zone, while above that many are in the wet-snow facies. These upper lakes rest on firn and are up to $95 \%$ ice-covered throughout the year. Surface areas of the lakes range from a few tens of square meters up to $10 \mathrm{~km}^{2}$, and depths appear to vary from less 
than $1 \mathrm{~m}$ to $20 \mathrm{~m}$, with deeper areas where the lakes cover crevasses. They tend to form in depressions found on the undulating surface of the ice sheet as shown by detailed surveys near the EGIG line (personal communication from M. Laternser). Some discharge through rivers or streams. The reduced albedo of the lakes and areas of saturated firn relative to the surrounding ice sheet cause greater absorption of sunlight and a concurrent increase in melting and, thus, a perpetuation of the lakes. Repeated photogrammetry and surveying shows that many large lakes remain fixed in space and that they are not advected along with the moving ice. This seems to imply that the larger surface depressions are tied to bedrock irregularities and are thus dynamically supported.

That many of the larger lakes are tied to a bedrock reference frame provides for an interesting and useful phenomenon. In those areas where the ice cover on these lakes is not totally removed during the summer, an area of open water forms at their up-glacier ends during the summer, and the remaining ice cover is advected downglacier. At the end of the melt season, this open water freezes over. In this manner, a series of "ogives" is formed, with a distinct band of ice formed each year.

Examples of such ogive sequences are found at lakes labeled 1 through 6 in Figure 2b. Two expanded parts of this image, one centered at about $69^{\circ} 02^{\prime} \mathrm{N}, 48^{\circ} 28^{\prime} \mathrm{W}$ and another at $69^{\circ} 04^{\prime} \mathrm{N}, 48^{\circ} 20^{\prime} \mathrm{W}$, are shown in Figure $10 \mathrm{a}, \mathrm{b}$ and $c$. The length scale on these images was obtained by interactive pixel positioning. Two lakes ( 1 and 2), each with a sequence of lake ogives, are shown in Figure 10a. The ogives are alternating dark and light bands. With some care, using clearer computer screen images, 14-15 ogives were counted in $3700 \mathrm{~m}$ along lake 1 , and 13 were counted in $3100 \mathrm{~m}$ along lake 2. Assuming that these lakes are not advected but that the surficial floating ice layer is, the implied surface velocities are then those given in Table 2. Pixel size and inaccuracies in the direction along which the length is to be measured introduces an error of about $10 \%$ in the ogive-derived speeds. Similar measurements at other lakes labeled in Figure $10 \mathrm{~b}$ and elsewhere give the other results shown in Table 2.

The comparison between the observed and "ogive"derived velocities is remarkably good. Thus, the spacing of annual "lake ogives" gives an accurate estimate of the surface velocity. Satellite-image analysis of these features would be possible over much of central and southern West Greenland, and could provide detailed knowledge of ice flow without any field work. Note that variations in ogive width could be caused by either changes in surface speed or, more likely, a meteorologically induced variation in the extent of open water within a lake between different melt seasons.

Ice blisters are another interesting feature of the Jakobshavns region. To the best of our knowledge, these features have not been previously documented or explained, but they have been the source of a heated debate by the local people. The blisters are of two types. The first are small, circular to oblong mounds, 3-8 $\mathrm{m}$ high and $7-20 \mathrm{~m}$ in diameter (Fig. 11), and are found in fields about $1 \mathrm{~km}^{2}$ in area near the equilibrium line (Part II) in the regions shown on Figure 1. Most of the mounds seem to be hollow, and those that are open for viewing are often partially water-filled, with an outer shell of candle-like ice
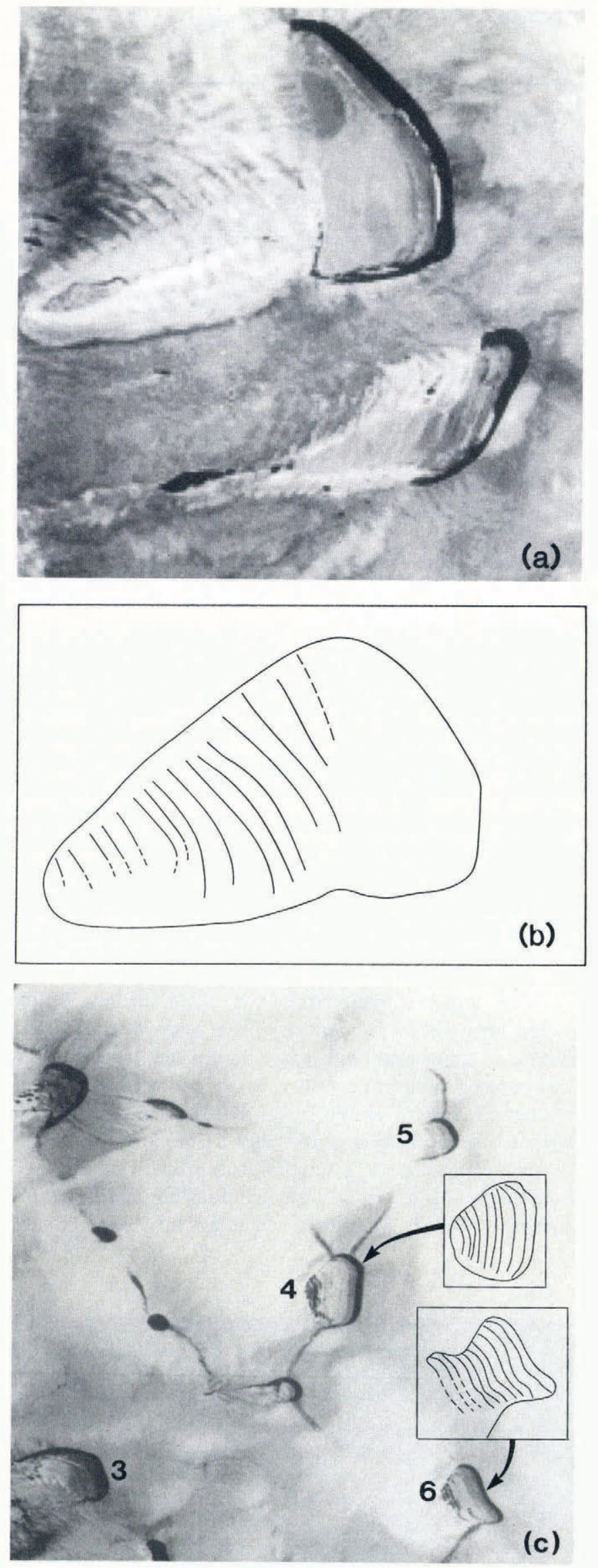

Fig. 10. (a) Enlargement of satellite image showing lakes 1 (top) and 2 (bottom), with "lake ogives". Pixel size is $50 \mathrm{~m}$. Flow direction is approximately from right to left and orientation is the same as in Figure 2b. Dark areas are open water. (b) Tracing of Figure 10a outlining ogives in lake 1. (c) Similar enlargement of lakes 3, 4, 5 and 6. Inset shows lake ogives on lakes 4 and 6 . 
Table 2. Velocity derived from lake ogives

\begin{tabular}{ccc}
\hline Lake & $\begin{array}{c}\text { Speed from } \\
\text { ogives } \\
\mathrm{m} \mathrm{a}^{-1}\end{array}$ & $\begin{array}{c}\text { Observed } \\
\text { speed }\end{array}$ \\
$\mathrm{m} \mathrm{a}^{-1}$ \\
\hline & & \\
1 & $295-320$ & 345 \\
2 & 238 & - \\
3 & 287 & - \\
4 & 275 & 266 \\
5 & 270 & 270 \\
6 & 183 & - \\
7 & 149 & 156 \\
(not shown) & & \\
\end{tabular}

"Observed speeds from Part III, except at lake 7, which is estimated from data of $\mathrm{H}$. Brecher and T. Hughes (personal communications).

which is typically $0.5-1 \mathrm{~m}$ thick. Nearly linear, en echélon rows of these blisters are sometimes found, with an orientation similar to that of crevasses found further upstream. These mounds generally form in flatter areas just down-glacier from zones of marginal crevassing. The second type of blister appears to be formed by exfoliation of ice slabs induced by "longitudinal" compression, or buckling from below caused by expansional freezing of trapped meltwater. This type of blister is generally not hollow and is not filled with water.

One possible explanation for those blisters of the former type which are partially filled with water is that a section of a crevasse with some meltwater trapped in it may move downstream into a more compressive region, raising the in-situ water level. During the winter, the surface of the standing water may freeze, forming candle ice in the process. The state of compression at the new location may then cause upward buckling of this frozen meltwater layer, forming a circular to oblong dome,

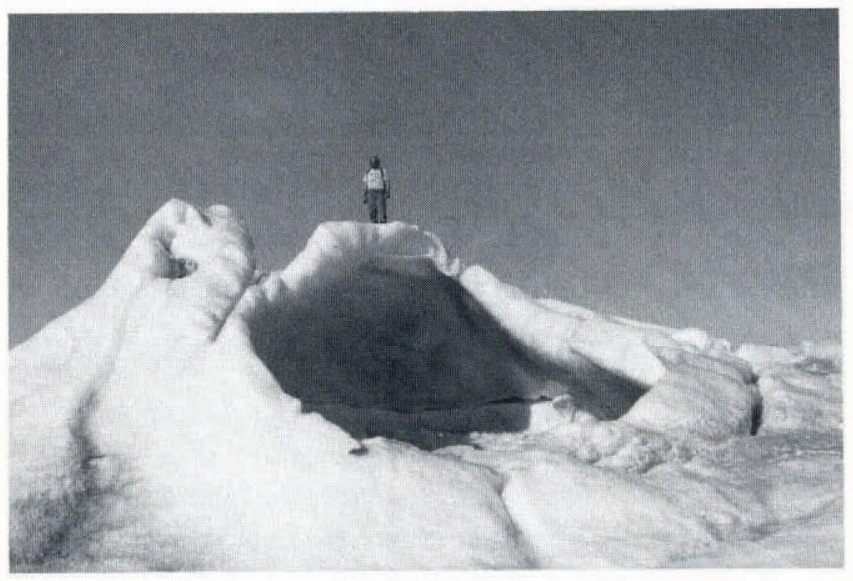

Fig. 11. Hollow ice blister near L23. Water fills the base of this structure. depending on the shape of the initial section of the crevasse that had the liquid trapped within it. This scenario requires the following: low surface-ice temperatures, rapid ice motion from a tensional to a compressive stress regime, and abundant meltwater which can be trapped in crevasses. The combination of these factors requires a specific geographic location and, possibly, an ice-stream environment. Some of the blister fields are located adjacent to meltwater lakes and are thus in relatively crevasse-free "depressions" with a locally compressive flow.

\section{SUMMARY AND DISGUSSION}

The surface morphology of Jakobshavns Isbræ is related to its rapid flow in a deep bedrock channel and to its termination in a floating section below the grounding zone. Many of the characteristics of this outlet-glacier/icestream system differ from those found on some of the West Antarctic ice streams, such as those terminating in the Ross Ice Shelf. However, these characteristics may possibly be indicative of those which will be found on some of the other important ice streams/outlet glaciers draining West Antarctica, such as Pine Island and Thwaites Glaciers. Jakobshavns Isbræ and these glaciers are not buttressed by a large, confined ice shelf. It is the relative stability of such unbuttressed ice streams which may prove to be an important factor in the overall response of the West Antarctic ice sheet to climatic change, for they do not appear to be undergoing rapid retreat at present, even through they lack ice-shelf buttressing.

The driving stresses along Jakobshavns ice stream are unusually large $(200-300 \mathrm{kPa})$, both because of the relatively large surface slopes $(0.01-0.03)$ and the large ice thickness within the channel (up to $2600 \mathrm{~m}$ ). These driving stresses are an order of magnitude or so larger than those of the ice streams of West Antarctica, and must, necessarily, give rise to high rates of internal deformation. And, although surface meltwater does not appear to influence the surface speed of the glacier (Echelmeyer and Harrison, 1990), the basal melt generated by the rapid motion may contribute, in a positive feed-back, to high rates of basal motion as well.

There does not appear to be a large bedrock (and, thus, surface) step at the transition from ice-sheet to icestream flow. This differs from many large outlet glaciers found in Antarctica (McIntyre, 1985), but the lack of such a feature is similar to some of the West Antarctic ice streams. Transverse to flow, the ice stream is concave, mimicking (with a greatly reduced amplitude) the subglacial trough in which it flows. At the margins of this surface concavity there are extensive crevasse fields. The width of the marginal crevasse zones is nearly as large as the ice stream itself. While this relative width is large, the absolute width of the crevasse zones $(\sim 5 \mathrm{~km})$ is similar to the absolute width of the zones found along the margins of West Antarctic ice streams.

The ice stream flows through a $90 \mathrm{~km}$ wide zone of surface melting, where supraglacial lakes and rivers occur. Linked to this meltwater production and also, in part, to the rapid ice-stream flow, are two unique surficial features: ice blisters and lake ogives. The blisters may require an 
ice-stream-type strain-rate environment for their formation. The width of the ogives is an indicator of surface speed and it may prove to be a useful tool elsewhere around the ice sheet.

Jakobshavns Isbræ extends several kilometers beyond the grounding zone as a floating tongue. This tongue is confined between fiord walls and terminates at an active calving front. There is one pinning point along the floating section which may play an important role in the stability of the glacier. At present, the position of the terminus appears to be relatively constant, but this does not necessarily imply that the glacier is in a steady state. It is likely that Jakobshavns Isbræ is adjusting its overall longitudinal profile to factors that caused its 100 year retreat and the resultant steepening in its lower reaches. The floating section may be stable to retreat only as long as the pinning point provides substantial back-stress. This back-stress could be reduced by a further thinning at the terminus.

At the same time as the ongoing adjustment to its 100 year retreat, Jakobshavns Isbræ may be affected by a possible, but controversial, thickening of the ice sheet within its drainage basin (e.g. Zwally, 1989; Douglas and others, 1990). A critical element in any balance assessment of such a thickening in the drainage basin is the flux of ice across the calving front. This calving flux is proportional to the ice thickness there. We have shown this thickness is significantly less than previous estimates (e.g. Bindschadler, 1984; Pelto and others, 1989), and thus the estimated outflow from the basin is less than that assumed by these authors. In Part II we further discuss the overall balance of this basin, with the incorporation of measured accumulation and ablation data along the lower reaches of the glacier.

\section{ACKNOWLEDGEMENTS}

This report would not have been possible without the help of many hard-working souls. These include the assistance of H. Brecher, D. Cosgrove, A. Iken, G. Liston, M. Lockwood, P. Moore, C. Petersen, J. Power, C. Quintana, D. Roberts, M. Sturm and C. Tobin. Logistical support from the PICO staff, especially S. Watson and $\mathrm{K}$. Swanson, was indispensable. H. Bay of GTO, Illulisat, helped in procuring hard-to-find items. A special thanks goes to the excellent helicopter pilots of Greenland Air Charter, in particular: K. Nordin, S. Olssen, J. Lindmark and Brigette; and to the helicopter mascot, Snoopy, for helping with the tricky landings.

The manuscript was prepared by C. Gering. H. Garbeil and J. Groves helped with the MOS imagery. H. Brecher provided an excellent mosaic of aerial photographs of the region, complete with ground control for scale. The editorial comments of $\mathrm{R}$. Hooke and an anonymous reviewer greatly improved the manuscript. 06818

This work was supported by U.S. NSF-DPP grant 84-

\section{REFERENCES}

Bauer, A. 1968. Missions aériennes de reconnaissance au Groenland 1957-1958. Medd. Gronl., 173(3).

Bindschadler, R.A. 1984. Jakobshavns glacier drainage basin: a balance assessment. J. Geophys. Res., 89(C2), 2066-2072.

Bindschadler, R.A., H.J. Zwally, J. Major and A. Brenner. 1989. Surface Topography of the Greenland ice sheet from satellite radar altimetry. Washington, DC, National Aeronautics and Space Administration. (NASA SP-503.)

Carbonnell, M. and A. Bauer. 1968. Exploitation des couvertures photographiques aériennes répétées du front des glaciers vêlant dans Disko Bugt et Umanak Fjord, juin-juillet 1964. Medd. Gronl., 173(5).

Clarke, T. and K. Echelmeyer. 1989. High resolution seismic reflection profiles across Jakobshavns Ice Stream, Greenland. EOS, 70(43), 1080. [Abstract.]

Douglas, B., R. Cheney, L. Miller, R. Ayreen, W. Carter and D. Robertson. 1990. Greenland ice sheet: is it growing or shrinking? Science, 248, 288-289.

Echelmeyer, K. In press. Surficial glaciology of Jakobshavns Isbræ: Part III. Velocity, calving and terminus fluctuations. J. Glaciol.

Echelmeyer, K. and W. D. Harrison. 1990. Jakobshavns Isbræ, West Greenland: seasonal variations in velocityor lack thereof. 7. Glaciol., 36(122), 82-88.

Echelmeyer, K., W. Harrison, T. Clarke and C. Benson. In press. Surficial glaciology of Jakobshavns Isbræ: Part II. Ablation, accumulation and temperature. 7. Glaciol. Hughes, T. 1975. The West Antarctic ice sheet: instability, disintegration and initiation of ice ages. Rev. Geophys. Space Phys., 13(4), 512-526.

Hughes, T. 1986. The Jakobshavns effect. Geophys. Res. Lett., 13(1), 46-48.

Hughes, T. In press. The pulling power of ice streams. $\mathcal{J}$. Glaciol.

Humphrey, N. and K. Echelmeyer. 1990. Hot-water drilling and bore-hole closure in cold ice. J. Glaciol., 36(124), 287-298.

Iken, A., K. Echelmeyer and W. Harrison. 1989. A lightweight hot water drill for large depth: experiences with drilling on Jakobshavns glacier, Greenland. In Rado, C. and D. Beaudoing, eds. Ice core drilling. Proceedings of the Third International Workshop on Ice Drilling Technology, Grenoble - France, 10-14 October 1988. Grenoble, Laboratoire de Glaciologie et Géophysique de l'Environnement, 123-136.

Lingle, C. S. 1978. Tidal flexure of Jakobshavns glacier. (M.S. thesis, University of Maine.)

Lingle, C.S., T.J. Hughes and R. C. Kollmeyer. 1981. Tidal flexure of Jakobshavns glacier, West Greenland. 7. Geophys. Res., 86(B5), 3960-3968.

McIntyre, N. F. 1985 The dynamics of ice sheet outlets. $\mathcal{J}$. Glaciol., 31(108), 99-107.

Meier, M. and A. Post. 1987. Fast tidewater glaciers. $\mathcal{J}$. Geophys. Res., 92(B9), 9051-9058.

Pelto, M.S., T.J. Hughes and H. Brecher. 1989. Equilibrium state of Jakobshavns Isbræ, West Greenland. Ann. Glaciol., 12, 127-131.

Power, J. and K. Echelmeyer. 1986. Passive seismic measurements on Jakobshavns Isbræ and their relation to iceberg calving and ice stream dynamics. In 1986 Chapman Conference on Rapid Glacier Flow, Whistler, B.C. Abstract volume. Washington, DC, American Geophysical Union, 23.

Quintana, C. and K. Echelmeyer. 1986. Ice fabric analysis 
from Jakobshavns glacier, Greenland. In 1986 Chapman Conference on Rapid Glacier Flow, Whistler, B.C. Abstract volume. Washington, DC, American Geophysical Union, 16.

Radok, U., R. G. Barry, D. Jenssen, R.A. Keen, G. N. Kiladis and B. McInnes. 1982. Climatic and physical characteristics of the Greenland ice sheet. Parts I and II. Boulder, CO, University of Colorado. Cooperative Institute for Research in Environmental Sciences.

Reeh, N. 1968. On the calving of ice from floating glaciers and ice shelves. 7. Glaciol., 7(50), 215-232.

Shabtaie, S., I. M. Whillans and C. R. Bentley. 1987. The morphology of ice streams A, B, and C, West Antarctica, and their environs. 7. Geophys. Res., 92(B9), 8865-8883.

Thomas, R.H. 1979. The dynamics of marine ice sheets. J. Glaciol., 24(90), 167-177.

Thomsen, H. H. 1987. Map of Jakobshavns Isbre and Pakisaq region, W. Greenland. Copenhagen, Grønlands Geologiske Undersøgelse.

Vornberger, P. and I. M. Whillans. 1986. Surface features of Ice Stream B, Marie Byrd Land, West Antarctica. Ann. Glaciol., 8, 168-170.

Warren, C. R. In press. Terminal environment, topographic control, and fluctuations of West Greenland glaciers. Boreas.

Weertman, J. 1957. Deformation of floating ice shelves. $\mathcal{F}$. Glaciol., 3(21), 38-42.

Weertman, J. 1973. Can a water-filled crevasse reach the bottom surface of a glacier? International Association of Scientific Hydrology Publication 95 (Symposium at Cambridge 1969 - Hydrology of Glaciers), 139-145.

Weidick, A. 1968. Observations on some Holocene glacier fluctuations in W. Greenland. Medd. Grenl., 165(6).

Weidick, A. 1990. The iceberg shoal at Ilulissat. IlulissatJakobshavn Tourist News, 28-31.

Zwally, H.J. 1989. Growth of Greenland ice sheet: interpretation. Science, 246(4937), 1589-1591.

The accuracy of references in the text and in this list is the resposibility of the authors, to whom queries should be addressed. 